\title{
Accrual earning management and future performance: Evidence from family firm in Indonesia
}

\author{
Edy Suprianto $^{1 *}$, Doddy Setiawan ${ }^{2}$ \\ ${ }^{1}$ Universitas Islam Sultan Agung, Semarang, Indonesia \\ ${ }^{2}$ Universitas Sebelas Maret, Surakarta, Indonesia \\ *Corresponding author email: edy_2806@yahoo.co.id
}

\section{A R T I C LE I N F O}

Article history:

Available online

\section{Keywords:}

Accrual Earning Management,

future cash flows, future net income

and family firms

DOI:

https://doi.org/10.20885/jaai.vol24.is

s1.art4

\section{A B S T R A C T}

The purpose reasearch is to examine the effect of earnings management on future performance. We also will assess whether auditor have important role in family firms. The population is all companies listed on the Indonesian stock exchanges from 2012 to 2014 (financial industry was excluded). The total sample used in this study as many as 918 firmyears or observations. Model by Kaznik (1999) model was used as an earning management proxy because it better than the other models. We suggest that the average value of the firms family future performance $\left(\mathrm{CFO}_{t+1}\right.$ and $\left.\mathrm{NI}_{t+1}\right)$ is greater than non-family firms. We also show that accrual earnings management in Indonesia is more efficiency than opportunistic. Accrual earning management which conducted by Family Firms is more efficient than Non-Family Firms. Finally, auditor in family firms will increase future performance.

\section{Introduction}

The importance of meeting or exceeding profits as benchmark of managers' performance measurements is of concern to some research. Thus, managers tend to try to meet the earnings benchmark by making earnings management. Management policies can improve earnings information by providing private information to outsiders; on the other hand incentive discrepancies between managers and shareholders can encourage managers to use the flexibility of accounting standards to act opportunistically by creating reported profit distortions (Watts \& Zimmerman, 1990).

Previous research by Graham et al. (2005)stated that accrual based earnings management negatively impact future performance. Cohen and Zarowin (2010) and Zhu et al. (2015) also provide new evidence in particular that earnings management tends to negatively affect future performance. These results support previous research conducted by Cornett et al. (2008, 2009), Healy (1985), and Jones (1991) That earnings management is called opportunistic earning management. On the other hand, Subramanyam (1996) and Krishnan (2003) revealed the other of earning management. It was the efficiency earnings management where earnings management is done to increase the value of the company and one of them is by increasing persistence earnings, the profitability of the company in the future or the quality of Profit (Gunny, 2010; Siregar \& Utama, 2008). The assumption is that management performs earnings management to influence the output of accounting system so as to provide better signal and performance in the future.

Wang (2006), Jung and Kwon, 2002), Warfield et al. (1995), and Chen and Chen (2008) found that family companies show higher earnings quality. This is because family companies have the advantage of disciplining and monitoring managers (Anderson and Reeb, 2003). So, that managers will act in accordance with the interests of shareholders (alignment).

The survey results from PWC in 20014 shows that more than 95\% of businesses in Indonesia are owned by families and in Southeast Asia, $60 \%$ of listed companies are also family firm. It is supported research which conducted by (Claessens et al., 2000; Habib et al., 2017; Mulyani et al., 2016; Porta et al., 2002). That survey explain that Indonesian family businesses are better than non-family firm, because they have more entrepreneurial and use the long-term approach in decision making so that more efficient. Family business has different governance than nonfamily firms. They have a informal family meetings to heavily structured, professional bodies such as family offices, family foundations and family committees designed for special purposes. Family Firms have a informal family meetings to heavily structured, professional bodies such as family offices, family foundations and family committees designed for special purposes (Jaffe \& Lane, 2004). They will choose auditor which has high quality. Bigger audit 
firms have higher audit quality too (Palmrose, 1988). They have some advantages like technology, human resources, and experience. Many research on earning management, but previous research rarely links with future performance and family firms (FF). This research will fill this gaps that haven't received attention previous research.

We make four contributions to the literature. First, we show that family firms future performance $\left(\mathrm{CFO}_{t+1}\right.$ and $\left.\mathrm{NI}_{\mathrm{t}+1}\right)$ is greater than the non-family firms future performance. Second, we found that earnings management in Indonesia is more efficiency than opportunistic. Third, we found that accrual earning management conducted by family companies have a significant positive effect on the future performance. Finally, bigger auditor firms which selected by family firms have positive effect on future performance.

\section{Literature Review}

\section{Agency Theory}

Jensen and Meckling (1976) describe the contractual relationship between the principal and the agent that tends to conflict. Principals hope to get the maximum profit, but agents also have the opportunity to maximize their own interests by managing earnings. This information asymmetry causes conflicts. There are agency costs incurred to reduce information asymmetry. These monitoring costs must be incurred by the principal by paying a third party to monitor the agent's behavior.

Watts and Zimmerman (1990) state that motivation of management to do earning management such is to obtain external contract incentives, management compensation contract incentives, motivation of regulation and capital market. According to Sevin and Schroeder (2005) management of company seeks to influence reported earnings in the short term to meet profit targets and earnings projection by analysts at the company. They use earnings management as tool to convey positive signal to investor about future performance through recent income (Subramanyam, 1996). Siregar and Utama (2008) suggest that accrual earning management in Indonesia has positive effect on future performance.

Previous research like Cohen and Zarowin (2010), Graham et al. (2005), and Zhu et al. (2015) provide evidence that earnings management is oportunistic. On the other hand, Subramanyam (1996), Krishnan (2003), Siregar and Utama (2008), and Gunny (2010) revealed that earning management is efficiency. Wang (2006), Jung and Young (2002), Warfield et al.(1995), Chen \& Chen (2008), and Anderson and Reeb (2003) found that family companies show higher earnings quality.

\section{Difference future performance of family firms and Non- family firms}

The survey results by PWC 2014 stated that more than 95\% of businesses in Indonesia are family owned and $60 \%$ of publicly listed companies (tbk.) In Southeast Asia are family companies. The results of this survey support research conducted by (Claessens et al., 2000; Habib et al., 2017; Mulyani et al., 2016). In the survey predicts that $100 \%$ of Indonesian family businesses have better growth due to several things: firstly, Indonesian family business plays an important role in job creation; secondly, Indonesian family businesses use the benchmark of success not only profit but also business growth, the three Indonesian family businesses are more entrepreneurial and use the long-term approach in decision making so that more efficient / faster, the four Indonesian family businesses have better defense mechanisms in the event of a recession.

Anderson and Reeb (2003) and Bouzgarrou and Navatte (2013) stated that family ownership positively affects the company's performance. This result is supported by research conducted by Adhikari and Sutton (2016) and Wang (2006) who concluded that the performance of family firms is better than non-family companies. Family firms can improve monitoring to managers or can align the interests of majority and minority shareholders to improve company performance. Based on the above explanation can be formulated hypothesis as follows: H1: future performance of family firms is better than non-family firms

\section{Earning Management in Indonesia and Future Performance}

Claessens et al. (2000), Mulyani et al. (2016) and Porta et al. (2002) state that firms which listed in Indonesia stock exchange was largely controlled by the family. In the agency theory Jensen and Meckling (1976) states that the existence of controlling shareholders can reduce agency costs and conflicts in order to improve the performance of the company and can reduce information asymmetry for external parties. Lins (2003) also adds that the controlling shareholder positively affects the value of the company, especially during the economic downturn. This is because when the control rights and cash flow rights owned by the majority shareholder increase, the interests of majority shareholders and minorities are aligned so that it will increase the value of the company (Mitton, 2002). Family firms have incentive and resources to monitor managers or can align the interests of majority and minority shareholders to improve company performance. Anderson and Reeb (2003) and Bouzgarrou and Navatte (2013) stated that family ownership positively affects the company's performance. This result is supported by research conducted by Adhikari and Sutton (2016) and Wang and Shailer (2017) who concluded that the performance of 
family enterprises is better than non-family companies. Based on the above explanation, it can be hypothesized in this research that:

H2: Type of accruals earnings management of family firm in Indonesia is more efficient than non-family firm.

\section{Earning Management in Family Firms Indonesia and Future Performance}

Razzaque et al. (2016) found that larger family firms did earnings management. Wang (2006) states that a familycontrolled company can use two ways of controlling the firm: entrenchment and alignment. Both ways have different consequences for the company's performance in the future. Family companies tend to entrenchment that tend to be opportunistic so that company performance becomes lower. This is because family-concentrated ownership tends to occur the expropriation of corporate resources at the expense of minority shareholder interests (Claessens et al., 2000; Porta et al., 2002).

On the other hand users of financial statements require better performance to protect their assets and interests. This is what motivates family companies to report higher earnings quality and improve long-term performance of the company. Subramanyam (1996) also explain how companies conduct earnings management through income smoothing with the aim to convey private information to investors about future profits. Based on the reported earnings rate allows investors to estimate the future level of future cash flows, on the contrary if reported earnings are too fluctuating, it will reduce investor confidence in the company's performance. Research conducted by Tucker and Zarowin (2006) shows that firms controlled by families perform earnings management have higher future performance than non-family companies. These results are supported by Subramanyam (1996) and Wang (2006). Based on the above explanation, it can be hypothesized in this research that:

H3: type of accruals earnings management which conducted by family firms more efficient than non-family firms.

\section{Earning Management, Auditor and Future Performance}

Family Firms have a informal family meetings to heavily structured, professional bodies such as family offices, family foundations and family committees designed for special purposes (Jaffe \& Lane, 2004). They will choose auditor which has high quality. Bigger audit firms have higher audit quality too (Palmrose, 1988). They have some advantages like technology, human resources, and experience. Advance technology can help auditor to found audit evidence more efficient and faster (Simunic, 1980) as audit judgment material. Bigger experience auditor will provide performance more effective than less experience auditor (Bonner \& Lewis, 1990). It will increase their future performance (Ashton \& Brown, 1980). We assumes that bigger auditor firms will can reduce manager opportunistic behavior to conduct accrual earning management. It can give motivation to manager to work more effective and efficient, so future performance will be better. It is supported by Jeong et al. (2007) suggest that investors respond more favorably to positive earnings audited by assigned auditors than to those audited by nonassigned auditors. Based on this views we formulate the hypothesis:

H4: Bigger auditor firms have positive effect on future performance

H5: Bigger auditor firms which selected by family firms have positive effect on future performance

\section{Reserach Method}

The population ware all of companies listed in Indonesia Stock Exchange. Samples is choosed used purposive sampling method with some criterias. First, companies financial reporting 2012 until 2018. Second, financial industry excluded from samples. Third, measurement all variables must be completed.

The variable of future performance which was measured with two approaches i.e. future cash flow $\left(\mathrm{LnCFO}_{\mathrm{t}+1}\right)$ and future Net Income $\left(\mathrm{LnNI}_{t+1}\right)$. Where, $\mathrm{CFO}_{\mathrm{t}+1}=$ cash flows operation in year $\mathrm{t}+1$ for firm i deflated by total asset $\mathrm{t}-1$, while $\mathrm{NI}_{\mathrm{t}+1}=$ net income before tax and interest in year $\mathrm{t}+1$ for firm i deflated by total asset $\mathrm{t}-1$. The variable of earning management was measured using three models of earning management i.e. Jones model (1991), Modified (Dechow et al., 1995), and Kaznik model (1999).

1. Jones model (1991) with equality model as follows:

$$
\frac{T A_{i t}}{A_{i t-1}}=\alpha_{i}\left[\frac{1}{A_{i t-1}}\right]+\beta_{1 i}\left[\frac{\Delta R E V_{i t}}{A_{i t-1}}\right]+\beta_{2 i}\left[\frac{P P E_{i t}}{A_{i t-1}}\right]+\varepsilon_{i t}
$$

2. Modified Jones model (1995) with this following equality model:

$$
\frac{T A_{i t}}{A_{i t-1}}=\alpha_{i}\left[\frac{1}{A_{i t-1}}\right]+\beta_{1 i}\left[\frac{\Delta R E V_{i t}-\Delta R E C_{i t}}{A_{i t-1}}\right]+\beta_{2 i}\left[\frac{P P E_{i t}}{A_{i t-1}}\right]+\varepsilon_{i t}
$$

3. Modified Kaznik model (1999) with equality model as follow:

$$
\frac{T A_{i t}}{A_{i t-1}}=\alpha_{i}\left[\frac{1}{A_{i t-1}}\right]+\beta_{1 i}\left[\frac{\Delta R E V_{i t}-\Delta R E C_{i t}}{A_{i t-1}}\right]+\beta_{2 i}\left[\frac{P P E_{i t}}{A_{i t-1}}\right]+\beta_{3 i}\left[\frac{\Delta C F O_{i t}}{A_{i t-1}}\right] \varepsilon_{i t}
$$




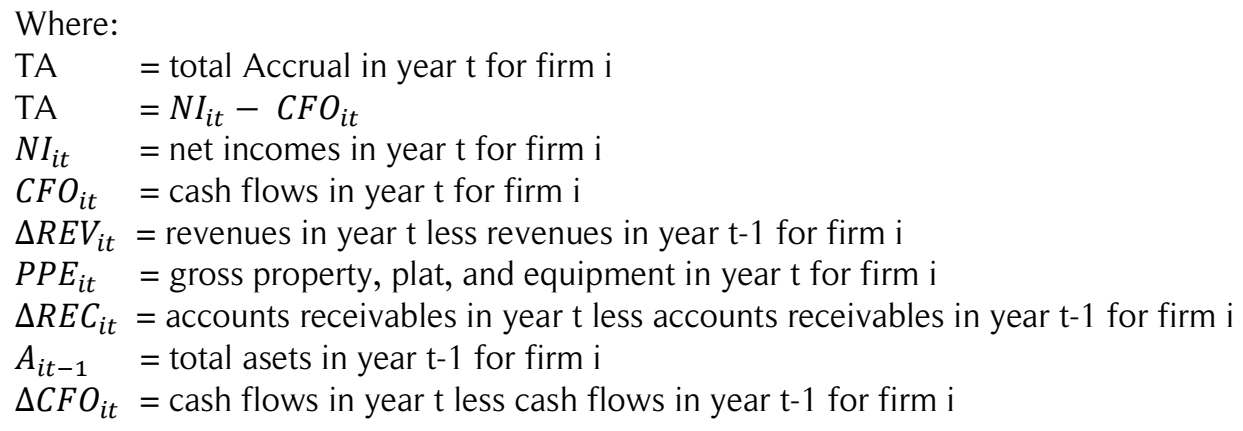

Technique of data analyses used in this study was multiple regressions with this equation:

$C F O_{t+1}=\alpha+\beta 1 \mathrm{DAC}+\beta 2$ Size $+\beta 3$ Lev $+\beta 4$ Prof $+\varepsilon .$. Model 1

$C F O_{t+1}=\alpha+\beta 1 \mathrm{MLA}+\beta 2 \mathrm{Kep}_{\text {Family }}+\beta 2 \mathrm{MLA} *$ Kep_F $+\beta 2 \operatorname{Size}+\beta 3 \mathrm{Lev}+\beta 4$ Prof $+\varepsilon$. Model 2

Where: $\mathrm{CFO}_{\mathrm{t}+1}$ as proxy of future performance, DAC is variable of earning management, family is family ownership which measured by used Prabowo and Simpson (2011) approach, family ownership is identified as the ownership of the individual (more than 20\%), 1 if family firm and 0 if non-family firm), Big4 is size audit firm (1 if audited by big4 and 0 for non-big4), DAC*Family is moderation variable between DAC and Family, Family* Big4 is moderation variable between Big4 and Family, Size is control variable of company size which is measured by In Total of Assets, Lev is control variable of leverage which is measured by debt to equity ratio and Prof is control variable of profitability which is measured by return on asset ratio.

\section{Results and Discussion}

Total population were 3.775 observation (firms-yeras). Companies included into financial industries were excluded from this study i.e. 583 companies because their character is not in line with. Besides, those with uncompleted data and have negative leverages were also excluded i.e. 1.959 companies. Therefore, there were 1.233 companies to be included in this study as a sample. Out of a total of 1.233 samples the total number of companies including family firms was 736 samples and 497 samples including non-family firms

Table 1. Sample of the Study

Panel A. Sampling Procedure

\begin{tabular}{|c|c|c|c|c|c|c|c|c|}
\hline Sample & 2012 & 2013 & 2014 & 2015 & 2016 & 2017 & 2018 & Total \\
\hline Total Companies & 482 & 506 & 514 & 534 & 542 & 595 & 602 & 3.775 \\
\hline Financial Company & (74) & (74) & (78) & $(87)$ & $(88)$ & (91) & (91) & $(583)$ \\
\hline Incomplete Data & $(288)$ & (312) & $(316)$ & $(224)$ & $(231)$ & $(287)$ & $(289)$ & (1959) \\
\hline Total Samples & 120 & 120 & 120 & 217 & 217 & 217 & 222 & 1.233 \\
\hline
\end{tabular}

Panel B. Sample distribution for every industry

\begin{tabular}{lrr}
\hline Industry & Total & $\%$ \\
Agriculture & 70 & 5.6 \\
Mining & 52 & 4.2 \\
Basic Industry and Chemicals & 265 & 22.5 \\
Miscellaneous Industry & 150 & 12.2 \\
Consumer Goods Industry & 151 & 12.2 \\
Property, Real Estate and Building & 133 & 10.8 \\
$\quad$ Construction & 115 & 9.3 \\
Infrastructure, Utilities and Transportation & 287 & 23.3 \\
Trade, Services \& Investment & 1.233 & 100 \\
Total &
\end{tabular}

Table 2 shows the data of descriptive statistic for each variable. The DAC variable (proxy of earnings management accruals) for the average family company is -0.051 whereas for non-family companies the average is 0.079. So these two groups of companies are different way to doing earnings management. FF (value of DAC is negative sign) tend to do earnings management accrual by decreasing income, while for NF (DAC value is positive sign) tend to do earnings management accruals by increasing income. In the $\mathrm{LnCFO}_{t+1}$ and $\mathrm{LnNI}_{\mathrm{t}+1}$ variable (future performance proxy) for FF is larger than NF. Auditor variable for $63.2 \%$ family firm is audited by big4, while $36.8 \%$ non-family firm is audited by big4. 
Table 2. Drescriptive Statistic

\begin{tabular}{llrrrrrrr}
\hline & \multicolumn{4}{c}{ Family } & \multicolumn{4}{c}{ Non-Family } \\
\cline { 2 - 8 } \multicolumn{1}{c}{ Note } & $\mathrm{N}$ & \multicolumn{1}{c}{ Mean } & \multicolumn{1}{c}{ Minimum } & Maximum & $\mathrm{N}$ & Mean & Minimum & Maximum \\
\hline DAC & 736 & -0.051 & -26.347 & 12.679 & 497 & 0.079 & -0.195 & 0.029 \\
LnCFO $_{\mathrm{t}+1}$ & 736 & 5.828 & -3.907 & 18.403 & 497 & 0.883 & 4.069 & 6.691 \\
LnNI $_{\mathrm{t}+1}$ & 736 & 6.683 & -3.548 & 18.668 & 497 & 0.574 & 5.368 & 7.125 \\
Big4 & 736 & 0.632 & 0 & 1 & 497 & 0.368 & 0 & 1 \\
LnAset & 736 & 3.092 & 10.168 & 1.321 & 497 & 6.172 & 20.708 & 39.093 \\
Lev & 736 & 2.352 & 0 & 91.652 & 497 & 0.335 & 1.674 & 2.811 \\
Prof & 736 & 2.441 & -86.921 & 54.318 & 497 & 1.815 & -0.890 & 4.495 \\
\hline
\end{tabular}

We used Siregar and Utama (2008) approach to measure earnings management: Jones model (1991) and Kaznik model (1999). Better model is model that get bigger value of R2. We just try on the data of the three-year average values (2012 to 2014). Value of Adjusted R² for Jones model (1991), Modified (Dechow et al., 1995), and Kaznik model (1999) were 0.306, 0.300 and 0.510 respectively. Because of the Kaznik (1999)model produces a higher Adjusted $\mathrm{R}^{2}$ value, so this model is chosen to measure accrual earning management for all years (2012 to 2018).

Table 3. The Results of Earnings Management Model Evaluation

\begin{tabular}{lcccc}
\hline \multirow{2}{*}{ Ket } & \multicolumn{4}{c}{ Udj-R2 } \\
\cline { 2 - 5 } & 2012 & 2013 & 2014 & Rata-rata \\
\hline Model Jones (1991) & 0.203 & 0.447 & 0.267 & 0.306 \\
Model Modified Kones (1995) & 0.184 & 0.454 & 0.261 & 0.300 \\
Model Kaznik (1999) & 0.540 & 0.669 & 0.322 & 0.510 \\
\hline
\end{tabular}

The first hypothesis in this study is whether there are differences in the performance of family companies with non-family companies. We used Mann-Whitney $U$ because the data is not normal distribution. Table 4 shows result of Mann-Whitney $U$, where the average value of the company's family future performance $\left(\mathrm{CFO}_{\mathrm{t}+1}\right.$ and $\left.\mathrm{NI}_{\mathrm{t}+1}\right)$ is greater than the future performance of non-family companies. These results support a survey conducted by PWC stating that the company has a better performance outlook in the future. So this result contrast with the research done by Prabowo and Simpson (2011)who found that family owned ownership has negatively affect on the company's performance. In this table we also can be seen that for the first hypothesis test, the significance value of Mann-Whitney $U$ test is 0.010 , since the significance value is less than $5 \%$, it is concluded that the first hypothesis is supported. So the performance of family companies and non-family companies is different. On the size variable seen that there is difference between family company with non-family company with significance value of 0.001 .

In table 5 model 2, we also see that family variable has positively effect on future performance $\left(\mathrm{CFO}_{\mathrm{t}+1}\right.$ and $\mathrm{NI}_{\mathrm{t}+1}$ ). Based on table 5, the coefficient value for Family variable with dependent variable CFOt +1 is 3.668 with significance level more than $5 \%$. So it is robustness test that family firms have better performance than nonfamily firm. This study also shows that family companies that have small assets but are able to produce greater profits, otherwise non-family companies that have large assets but produce smaller benefits. This is in accordance with research conducted by Adhikari and Sutton (2016), Anderson and Reeb (2003), Bouzgarrou and Navatte (2013), and Wang and Shailer (2017) who concluded that the performance of family firms is better than non-family companies. This is because the family companies can improve monitoring to managers or can align the interests of majority and minority shareholders to improve the company's performance. This result is also in line with agency theory which states that the existence of controlling shareholders can reduce agency costs and conflicts so as to improve company performance and can reduce information asymmetry for external parties.

Table 4. Result of Mann-Whitney U test

\begin{tabular}{llcccc}
\hline \multicolumn{1}{c}{ Group } & $\mathrm{N}$ & Mean Rank & $\mathrm{Z}$ & Asymp. Sig. (2-tailed) \\
\hline LnCFO $_{\mathrm{t}+1}$ & non- Family & 497 & 331.218 & -1.964 & 0.010 \\
& Family & 736 & 576.127 & & \\
& Total & 1.233 & & & \\
$\mathrm{LnNI}_{\mathrm{t}+1}$ & non- Family & 497 & 310.901 & -4.553 & \\
& Family & 736 & 587.800 & & \\
& Total & 1.233 & & & \\
\hline
\end{tabular}


Based on the result of regression test in Table 5, it is found that the coefficient of DAC (earnings management) variable was 0,358 with significantly level at $5 \%$ level on future cash flow (model 1). It can be concluded that earnings management tended to positively affect company's future cash flow, so it can be said that earnings management in Indonesia is more efficiency than opportunistic. So the second hypothesis is accepted. If accrual earning management is increase, future cash flow will increase also and otherwise.

Table 5. Regression of Earnings Management (DAC) and Future Performance

\begin{tabular}{|c|c|c|c|c|c|c|c|}
\hline \multirow{2}{*}{$\begin{array}{l}\text { Independent } \\
\text { Variable }\end{array}$} & \multirow{2}{*}{$\begin{array}{c}\text { Predict } \\
\text { Sign }\end{array}$} & \multicolumn{4}{|c|}{$\mathrm{CFO}_{\mathrm{t}+1}$} & \multicolumn{2}{|r|}{$\mathrm{NI}_{\mathrm{t}+1}$} \\
\hline & & $\begin{array}{c}\text { Model } 1 \\
(\beta)\end{array}$ & $\begin{array}{c}\text { Model } 2 \\
(\beta)\end{array}$ & $\begin{array}{c}\text { Model } 3 \\
(\beta)\end{array}$ & $\begin{array}{c}\text { Model } 1 \\
(\beta)\end{array}$ & $\begin{array}{c}\text { Model } 2 \\
(\beta)\end{array}$ & $\begin{array}{c}\text { Model } 3 \\
(\beta)\end{array}$ \\
\hline Constant & $?$ & $5.926 * *$ & $5.911 * *$ & $5.652 * *$ & $4.601 * *$ & $4.638 * *$ & $4.416 * *$ \\
\hline DAC & + & $0.358 * *$ & $0.366 * *$ & $0.280 * *$ & $0.387 * *$ & $0.397 * *$ & $0.440 * *$ \\
\hline Big4 & + & & $0.276 * *$ & $0.763 * *$ & & $0.300 * *$ & $0.651 *$ \\
\hline Family & + & & $0.167 * *$ & $0.276^{* *}$ & & $0.270 * *$ & $0.094 *$ \\
\hline DAC*Family & + & & & $0.501 * *$ & & & $0.595 * *$ \\
\hline Family*Big4 & + & & & $0.900 * *$ & & & $0.627 * *$ \\
\hline \multicolumn{8}{|l|}{ Var Control: } \\
\hline Size & - & $0.000 * *$ & $0.000 * *$ & $0.000 * *$ & $0.000 * *$ & $0.000 * *$ & $-0.000 * *$ \\
\hline Leverage + & & $0.068 * *$ & $0.071 *$ & $0.068 *$ & $0.099 * *$ & $0.102 * *$ & $-0.101 * *$ \\
\hline Profitability & + & $0.038 * *$ & $0.037 * *$ & $0.035^{*}$ & $0.094 * *$ & $0.092 * *$ & $0.089 * *$ \\
\hline \multicolumn{8}{|l|}{ Fixed Effect: } \\
\hline Cross_Section & & Yes & \multicolumn{2}{|c|}{ Yes Yes } & Yes & \multicolumn{2}{|l|}{ Yes Yes } \\
\hline Total Obs & & 1.233 & \multicolumn{2}{|c|}{1.2331 .233} & 1.233 & \multicolumn{2}{|c|}{1.2331 .233} \\
\hline Adjusted R2 & & 0.234 & \multicolumn{2}{|c|}{0.2360 .247} & 0.275 & \multicolumn{2}{|c|}{0.2780 .298} \\
\hline F (Statistic) & & 312.57 & \multicolumn{2}{|c|}{314.65333 .58} & 343.66 & \multicolumn{2}{|c|}{347.12381 .60} \\
\hline Probability & & 0.000 & \multicolumn{2}{|c|}{0.0000 .000} & 0.000 & \multicolumn{2}{|c|}{0.0000 .000} \\
\hline
\end{tabular}

** Significant at level 5\%, * Significant at level 10\%

This finding is supports the previous study which was conducted by Siregar and Utama (2008) who stated that earnings management positively affects on the firm future performance in Indonesia. But it is not in line with the study which was conducted by Cohen and Zarowin (2010), Graham et al. (2005) and Zhu et al. (2015) which suggest that earnings management negatively affects on the firm future performance in Indonesia. In table 5 as robustness test, we also can see that the other future performance $\left(\mathrm{NI}_{\mathrm{t}+1}\right)$ was positively effected by accrual earning management significant at 5\% level. Managers increase or decrease incomes to meet the certain private purposes for examples bonus plan or political objectives (Cornett et al., 2008, 2009; Healy, 1985b; Jones, 1991). They take advantage of accrual discretionary form accounting standard to increase or decrease recent incomes and it is can reduce future incomes and cash flows.

Table 5 above also shows the results of the third hypothesis testing that states whether the type of earnings management accrual by family firms is more efficient than non-family companies. Based on table 5 , the coefficient value for moderation variable between DAC and Family is 0.501 with significance level less than $5 \%$. So it can be concluded that the accrual earning management conducted by family companies have a significant positive effect on the company's performance in the future, in other words that accrual earnings management of family firms more efficient than non-family companies. It means that third hypothesis is accepted.

Table 5 above also shows the results of the fourth hypothesis testing that states whether the type of auditor have positively effect on future performance. Based on table 5, the coefficient value for Big4 variable with dependent variable CFOt +1 is 0.276 with significance level less than $5 \%$. So we can suggest that big4 auditor can increase firm future performance. It means that fourth hypothesis is accepted. While for moderate variables DAC * Family obtained coefficient value of 0.900 with significance level less than $5 \%$. So it can be concluded that auditor have role important in audited the accrual earning management conducted by family companies have a significant positive effect on the company's performance in the future. It means that fifth hypothesis is accepted. In other words that auditor can protect manager to do accrual earnings management opportunistically. Auditor provide guarantee that financial statement will give positive signal on investor that firm future performance will better. 
The family Firms is very instrumental in creating value and company performance because the family has a strong psychological attachment and commitment to the organization than others (Arthurs \& Busenitz, 2003). The company will show better performance and value if there is involvement from the founder or his family because the founder tends to show a higher need for achievement. On the other hand, the non-founder owner does not always have the commitment and track record like that of the founder family

To support the results of this second hypothesis test we tried to do robustness test by separating samples between family companies and non-family companies. Based on the results of the analysis in table 6 below, it shows that good for family company group shows the result where the coefficient value of DAC to CFOt +1 is 0,231 at significance level less than $5 \%$. Unlike the non-family enterprise group, the value of DAC coefficient to CFOt +1 is -0.331 at a significance level of more than $10 \%$. So it can be concluded that the accrual income management conducted by the family company has a significant positive effect on the company's future performance, while the accrual income management conducted by non-family companies has a significant negative effect on the company's performance in the future. In other words, the type of earnings management accrual by family firms is more efficient than non-family companies. These results support research conducted by Tucker and Zarowin (2006) indicating that family-controlled firms perform earnings management have higher future performance than non-family companies. So accrual earnings management is done by family firms to give positive signals to outsiders about upcoming company performance, whereas managers in non-family companies tend to make accrual earnings management a tool for expropriating shareholder funds.

Table 6. Regression Result of Accrual Earnings Management \& Future Cash Flow (Family Vs Non-Family Firms)

\begin{tabular}{|c|c|c|c|c|c|}
\hline \multirow[t]{2}{*}{ Independent Variable } & \multirow[t]{2}{*}{ Predict Sign } & \multicolumn{2}{|c|}{ Family } & \multicolumn{2}{|c|}{ Non_Family } \\
\hline & & $(\beta)$ & (Prob) & $(\beta)$ & (Prob) \\
\hline Constant & $?$ & 3.042 & 0.000 & 4.186 & 0.024 \\
\hline DAC & - & $0.231 * *$ & 0.006 & -0.331 & 0.101 \\
\hline \multicolumn{6}{|l|}{ Var Control: } \\
\hline Size & - & $0.000 * *$ & 0.000 & $0.020 * *$ & 0.000 \\
\hline Leverage - & & 0.123 & 0.217 & 0.117 & 0.143 \\
\hline Profitability & + & 0.019 & 0.728 & 0.018 & 0.156 \\
\hline \multicolumn{6}{|l|}{ Random Effect: } \\
\hline Cross_Section & & \multicolumn{2}{|c|}{ Yes } & \multicolumn{2}{|c|}{ Yes } \\
\hline Total Obs & & \multirow{2}{*}{\multicolumn{2}{|c|}{$\begin{array}{c}736 \\
0.254\end{array}$}} & \multicolumn{2}{|c|}{497} \\
\hline Udjusted R2 & & & & \multicolumn{2}{|c|}{0.200} \\
\hline F (Statistic) & & \multicolumn{2}{|c|}{129.36} & \multirow{2}{*}{\multicolumn{2}{|c|}{$\begin{array}{c}123.16 \\
0.000 \\
\end{array}$}} \\
\hline Probability & & \multicolumn{2}{|c|}{0.000} & & \\
\hline
\end{tabular}

** Significant at level 10\%

In order to support the finding, we also try to divide two group above (FF and NF) based on sign of accrual earning management (positive and negative sign). Table 7 shows how behavior of firm manager manipulate recent income will effect firm future performance both cash flows and net income. In the family group, there are difference result between positive DAC and negative DAC. In positive DAC, value of DAC coefficient is 0.222 with significance level less than $5 \%$. This result can be suggested that manager try to increase recent firm incomes to improve their cash flows in the future. While in negative DAC, value of DAC coefficient is -0.125 with significance level more than $10 \%$, manager try to decrease recent for improve their future cash flows. So it can be concluded that accrual earnings management conducted by FF tended to give positive information for external shareholder.

On the other hand, in the non-family group, there are also difference result between positive DAC and negative DAC. In positive DAC, value of DAC coefficient is -0.023 with significance level $5 \%$. This result can be suggested that manager try to increase recent firm incomes to reduce their cash flows in the future. While in negative DAC, value of DAC coefficient is 0.157 with significance level more than $10 \%$, manager try to decrease recent for decrease their future cash flows. So it can be concluded that accrual earnings management conducted by NF tended to expropriate shareholder fund for private interest. In others word that accrual earnings management which conducted by NF tend to opportunistic than efficiency. 
Table 7. The Difference Way To Difference of Accrual Earnings Management Type between Family Firms and Non-Family Firms

\begin{tabular}{|c|c|c|c|c|c|}
\hline \multirow{2}{*}{ Independent Variable } & \multirow{2}{*}{ Predict Sign } & \multicolumn{2}{|c|}{ Family } & \multicolumn{2}{|c|}{ Non_Family } \\
\hline & & (Positive DAC) & $\begin{array}{c}\text { (Negative } \\
\text { DAC) }\end{array}$ & (Positive DAC) & $\begin{array}{c}\text { (Negative } \\
\text { DAC) }\end{array}$ \\
\hline Constant & $?$ & 5.121 & 3.220 & 4.046 & 3.295 \\
\hline DAC & - & $0.222 * *$ & -0.125 & $-0.023 * *$ & 0.157 \\
\hline \multicolumn{6}{|l|}{ Var Control: } \\
\hline Size & - & $0.000^{* *}$ & 0.000 & $0.000 * *$ & 0.000 \\
\hline Leverage - & & $0.001 * *$ & 0.003 & $0.015^{* *}$ & 0.002 \\
\hline Profitability & + & $0.002 * *$ & 0.010 & $0.006^{* *}$ & 0.001 \\
\hline \multicolumn{6}{|l|}{ Random Effect: } \\
\hline Cross_Section & & Yes Yes & & Yes Yes & \\
\hline Total Obs & & 736736 & & 497497 & \\
\hline Udjusted R2 & & 0.1060 .271 & & 0.1030 .266 & \\
\hline F (Statistic) & & 123.79122 .632 & & 101.94122 .91 & \\
\hline Probability & & 0.0000 .000 & & 0.0000 .000 & \\
\hline
\end{tabular}

** Significant at level 5\%

\section{Conclusion}

This research gives evidence that the average value of the company's family future performance $\left(\mathrm{CFO}_{t+1}\right.$ and $\left.\mathrm{NI}_{t+1}\right)$ is greater than the future performance of non-family companies. We also suggest that the type of earnings management in Indonesia tends to be rather opportunistic than efficiency. Finally, bigger auditor firms which selected by family firms have positive effect on future performance. This research proves that future performance family firms is better than non-family firms. This research have implication that investors should consider investing more in family companies. Family firms must maintain its performance to maintain the good name of the family.

This research has some limitations of research such as 1) value of Adj-R2 equal to 24,7\% (Table 5 model 3), future research can add variables of corporate governance (eg commissioners, audit committees, institutional or governmental ownership and other variables) that may affect earnings management in Indonesia. 2) Determination of group of family companies and not still very simple, further research can still separate between single and double family control or by separating between family managers with no

\section{References}

Adhikari, H. P., \& Sutton, N. K. (2016). All in the family: The effect of family ownership on acquisition performance. Journal of Economics and Business, 88, 65-78.

Anderson, R. C., \& Reeb, D. M. (2003). Founding-family ownership and firm performance : Evidence from the S \& P 500. The Journal of Finance, 58(3), 1301-1328.

Arthurs, J. D., \& Busenitz, L. W. (2003). The boundaries and limitations of agency theory and stewardship theory in the venture capitalist/entrepreneur relationship. Entrepreneurship Theory and Practice, 28(2), 145-162.

Ashton, R. a, \& Brown, P. R. (1980). Descriptive Modeling of Auditors' Internal Control Judgments: Replication and Extension. Journal of Accounting Research, 18(1), 269-277. https://doi.org/10.2307/2490402

Bonner, S. E., \& Lewis, B. L. (1990). Determinants of auditor expertise. Journal of Accounting Research, 28, 1-20.

Bouzgarrou, H., \& Navatte, P. (2013). Ownership structure and acquirers performance: Family vs. non-family firms. International Review of Financial Analysis, 27, 123-134.

Chen, X., \& Chen, S. (2008). Do family firms provide more or less voluntary disclosure ? Journal of Accounting Research, 46, 499-536. https://doi.org/10.1111/j.1475-679X.2008.00288.x

Claessens, S., Djankov, S., \& Lang, L. H. . (2000). The separation of ownership and control in East Asian Corporations. Journal of Financial Economics, 58(2), 81-112.

Cohen, D. A., \& Zarowin, P. (2010). Accrual-based and real earnings management activities around seasoned equity 
offerings. Journal of Accounting and Economics, 50(1), 2-19. https://doi.org/10.1016/j.jacceco.2010.01.002

Cornett, M. M., Marcus, A. J., \& Tehranian, H. (2008). Corporate governance and pay-for-performance: The impact of earnings management. Journal of Financial Economics, 87(2), 357-373.

Cornett, M. M., McNutt, J. J., \& Tehranian, H. (2009). Corporate governance and earnings management at large U.S. bank holding companies. Journal of Corporate Finance, 15(4), 412-430.

Dechow, P. M., Sloan, R. G., \& Sweeney, A. P. (1995). Detecting earnings management. The Accounting Review, 70(2), 93-225.

Graham, J. R., Harvey, C. R., \& Rajgopal, S. (2005). The economic implications of corporate financial reporting. Journal of Accounting and Economics Volume 40, Issues 1-3, December 2005, Pages, 40(1), 3-73.

Gunny, K. A. (2010). The relation between earnings management using real activities manipulation and future performance: Evidence from meeting earnings benchmarks. Contemporary Accounting Reserach, 27(3), $855-888$.

Habib, A., Muhammadi, A. H., \& Jiang, H. (2017). Political connections and related party transactions : Evidence from Indonesia. The International Journal of Accounting, 52(1), 45-63.

Healy, P. M. (1985a). The effect of bonus schemes on accounting decisions. Journal of Accounting and Economics, 7(1-3), 85-107.

Healy, P. M. (1985b). The effect of bonus schemes on accounting decisions. Journal of Accounting and Economics, 7, 85-107.

Jaffe, D. T., \& Lane, S. H. (2004). Sustaining a family dynasty: Key issues facing complex multigenerational business- and investment-owning families. Family Business Review, 17(1), 5-18.

Jensen, C., \& Meckling, H. (1976). Theory of the Firm : Managerial behavior, agency costs and ownership structure. 3, 305-360.

Jeong, S. W., Kim, J., \& Yoon, S. (2007). Assigned auditors and market valuation: Korean evidence. Accounting Research Journal, 20(1), 37-46.

Jones, J. J. (1991). Earnings management during import relief investigations. Journal of Accounting Research, 29(2), 193-228.

Jung, K., \& Kwon, S. Y. (2002). Ownership structure and earnings informativeness: Evidence from Korea. International Journal of Accounting, 37(3), 301-325. https://doi.org/10.1016/S0020-7063(02)00173-5

Kaznik, R. (1999). On the association between voluntary disclosure and earnings management. Journal of Accounting Research, 37(1), 57-81.

Krishnan, G. V. (2003). Audit quality and the pricing of discretionary accruals. Auditing, 22(1), 109-126. https://doi.org/10.2308/aud.2003.22.1.109

Lins, K. V. (2003). Equity ownership and firm value in emerging markets. The Journal of Financial and Quantitative Analysis, 38(1), 159-184.

Mitton, T. (2002). A cross-firm analysis of the impact of corporate governance on the East Asian financial crisis. Journal of Financial Economics, 64(2), 215-241.

Mulyani, E., Singh, H., \& Mishra, S. (2016). Dividends, leverage, and family ownership in the emerging Indonesian market. Journal of International Financial Markets, Institutions and Money, 43, 16-29.

Palmrose, Z.-V. (1988). Analysis of auditor litigation and audit service quality. The Accounting Review, 63(1), 5573. https://doi.org/10.2307/247679

Porta, R. La, Lopez-De-Silanes, F., Shleifer, A., \& Vishny, R. (2002). Investor protection and corporate valuation. The Journal of Finance, LXII(3), 1147-1170.

Prabowo, M., \& Simpson, J. (2011). Independent directors and firm performance in family controlled firms: evidence from Indonesia. Asian-Pacific Economic Literature, 25(1), 121-132.

Razzaque, R. M. R., Ali, M. J., \& Mather, P. R. (2016). Real earnings management in family firms: Evidence from an emerging economy. Pacific-Basin Finance Journal, 40(Part B), 237-250. 
Sevin, S., \& Schroeder, R. (2005). Earnings management: evidence from SFAS No. 142 reporting. Managerial Auditing Journal, 20(1), 47-54.

Simunic, D. A. (1980). The pricing of audit services: Theory and evidence. Journal of Accounting Research, 18(1), 161-190.

Siregar, S. V. N. P., \& Utama, S. (2008). Type of earnings management and the effect of ownership structure, firm size, and corporate-governance practices: Evidence from Indonesia. International Journal of Accounting, 43(1), 1-27.

Subramanyam, K. R. (1996). The pricing of discretionary accruals. Journal of Accounting and Economics, 22(1-3), 249-281.

Tucker, J. W., \& Zarowin, P. A. (2006). Does income smoothing improve earnings informativeness? The Accounting Review, 81(1), 251-270.

Wang, D. (2006). Family ownership and earnings quality. Journal of Accounting Research, 44(3), 619-656. https://doi.org/10.1111/j.1475-679X.2006.00213.x

Wang, K. T., \& Shailer, G. (2017). Family ownership and financial performance relations in emerging markets. International Review of Economics \& Finance, 51, 82-98.

Warfield, T. D., Wild, J. J., \& Wild, K. L. (1995). Managerial ownership, accounting choices, and informativeness of earnings. Journal of Accounting and Economics, 20(1), 61-91.

Watts, R. L., \& Zimmerman, J. L. (1990). Positive accounting theory: A ten year perspective. The Accounting Review, 65(1), 131-156.

Zhu, T., Lu, M., Shan, Y., \& Zhang, Y. (2015). Accrual-based and real activity earnings management at the back door: Evidence from Chinese reverse mergers. Pacific-Basin Finance Journal, 35(Part A), 317-339. 